\title{
Accrual Accounting Change: Malaysian Public Sector Readiness
}

\author{
Ruhaya Atan \\ Accounting Research Institute, Faculty of Accountancy, Universiti Teknologi MARA \\ 40450 Shah Alam Selangor, Malaysia
}

Tel: 60-3-5544 4979 E-mail: ruhaya@salam.uitm.edu.my

Faziyatun Mohamed Yahya (Corresponding author)

Accounting Research Institute, Faculty of Accountancy, Universiti Teknologi MARA

40450 Shah Alam Selangor, Malaysia

Tel: 60-12-221-0580Ｅ-mail: faziyatunmy@gmail.com

Received: Sep. 13, 2014 Accepted: December 24, 2014 Published: February 1, 2015

doi:10.5296/jmr.v7i2.6978 URL: http://dx.doi.org/10.5296/jmr.v7i2.6978

\begin{abstract}
The federal government decision to implement accrual-based accounting in Malaysia under the Government Transformation Programme (GTP) led to major changes in public finance management. To ensure the reforms achieve the target, the behaviour and mindset of employees must be ready. Therefore, this preliminary study will determine which attributes measure the readiness for change among public sector accounting personnel in Malaysia. This study also investigates any significant difference between demographic factors (position and length of service) and readiness for change. A survey was conducted of 119 public sector accounting personnel consisting of accountants, assistant accountant 1 and assistant accountant 2 in respect of their readiness to adopt accrual accounting in various ministries in Malaysia. The objectives of the study have been tested using descriptive analysis and ANOVA. The general findings show that the respondents have positive behaviour concerning readiness for change to accrual-based accounting. However, the results show that they are slightly disagree to take responsibility if the accounting change fails in their area. This study proves that the demographic factors of position and length of service are not related to readiness for change. These results are important for the government in order to strategize the effective guidelines for change interventions to ensure the successful implementation of accrual accounting in Malaysia.
\end{abstract}

Keywords: Accounting personnel, Malaysian public sector, Readiness for change 


\section{Introduction}

Public sector reforms started 30 years ago with the aim being to ensure the effectiveness, efficiency and transparency of operational and financial management in the public sector (Broadbent \& Guthrie, 1992; Guthrie \& Humphrey, 1996; Pallot, 1992). The New Public Management (NPM) is a set of contemporary administrative changes that aim to improve public sector efficiency and performance in output delivery (Siddiquee, 2006). Under the NPM, the accrual accounting basis is the vital change for the public sector management (Barton, 2005; Ellwood \& Newberry, 2007; Wynne, 2004). This new approach will reduce or remove differences between the public and private sectors as well as emphasize accountability in terms of results (Hood, 1995). The public sector organizations in developed and developing countries are subjected to the NPM reforms.

The Malaysian public sector reforms started in 1981. The main documents that gave fresh momentum for the future direction of Malaysia to become a fully developed nation are the National Development Policy (NDP) and Vision 2020 (Siddiquee, 2006). The journey of Malaysia as a developing country towards achieving a fully developed nation and high-income economy began in 2010. To meet the challenge in achieving Vision 2020, the development path requires structural reforms and a change in mindset. Hence, the Government Transformation Programme (GTP) and New Economic Model (NEM) constitute the roadmap for transforming government fiscal discipline to ensure effectiveness and efficiency (Ministry of Finance Malaysia, 2011). Migration to accrual accounting under the NEM reforms will put the Malaysian public sector finance practices in line with developed countries. The targets are to support the sustainability of fiscal policies and accountability of the results.

The public sector in Malaysia can be categorised into three tiers of government: federal, state and local (Isa, Saleh, \& Jusoh, 2011; Othman et al., 2007). In Malaysia, due to the accrual-based accounting transformation, the strategy, structure and process of public sector organizations will be changed. Support from employees is important to determine whether or not the change activities succeed (Peach, Jimmieson, \& White, 2005). Employee readiness for change is argued as being one of the most important factors that affect the success of the change effort (Armenakis, Harris, \& Mossholder, 1993; Shah \& Shah, 2010). In order to ensure that the reform achieves the target set, employee behaviour and belief should be positive, and they should be ready to accept the changes and believe that the transformation will have positive implications for themselves and the organization. Therefore, the organization should understand the individual readiness factors associated with acceptance or rejection for organizational change (Cunningham et al., 2002). Hence, the main objective of this study is to determine the behaviour attributes of public sector accounting personnel towards readiness for change. The specific objectives are as follows:

1. To determine which attributes measure the readiness for change among the public sector accounting personnel.

2. To examine whether job position and length of service are associated with readiness for change. 


\section{Review of Literature}

The spectrum of accounting basis ranging from cash, modified cash, modified accrual and full accrual (Baker \& D. Rennie, 2006). The Malaysian federal government has been using cash based accounting since independence. In 1974 the federal government adopted the modified cash based accounting (Saleh, Isa, \& Hasan, 2012). Due to government expansion in activities and limited economic resources, a move to accrual-based accounting is a vital decision to put Malaysia at the same level as developed countries. The argument being that this transformation will provide better financial reporting, reflect the actual financial position and provide the full cost of services (Saleh \& Pendlebury, 2006). However, the move is not without its challenges. As accrual accounting represents a change in the system, both organizational and individual factors that influence the change must be identified and managed effectively to ensure the successful implementation of the accounting system.

Employees' readiness for change can be explained to the extent concerning how individual employees hold positive views about the need for the organization to change. They must believe that the changes are likely to have positive implications for them and the organization (Armenakis et al., 1993). Previous research emphasized that support from employees was important to determine whether change initiatives will be a success or failure (Armenakis et al., 1993; Kavaliauskaite \& Jucevicius, 2010; Peach et al., 2005; Vakola, 2014). The individual readiness factors associated with the acceptance or rejection of organizational change have been explored by the researcher.

Although somewhat limited, the relationship between various demographic factors and readiness for change has been reported in previous research (Hanpachern, Morgan, \& Griego, 1998; Madsen, Miller, \& John, 2005; Shah \& Shah, 2010). Due to the lack of consensus concerning these factors in the literature, it is important to continue studying the relationship between the demographic factors and readiness for change. This is essential in order to assist practitioners to strategize effective change intervention guidelines. In previous research findings related to these demographic relationships, Hanpachern et al. (1998) stated that readiness for change was related to position, length of employment and department but not related to age, gender, education or marital status. Weber \& Weber (2001) found that readiness for change was not related to age, organization, work experience and education. Cunningham et al. (2002) confirmed that there was no relationship between readiness for change with gender and marital status. Madsen et al. (2005) found that the numbers of children were significantly related to readiness for change but that gender, age, marital status, education, length of time and company were not related to readiness for change. Finally Shah \& Shah (2010) concluded that present employment status and number of dependents were related to readiness for change, however, there was no relationship between readiness for change and gender, age, marital status, education, years with present job or years with present employer.

\section{Methods}

This preliminary study is a quantitative design using the survey method. The survey was conducted in various ministries in Malaysia. Due to the federal government decision to adopt accrual accounting, all 23 ministries became self-accounting departments with the accounts 
division (AD) playing a vital role as an accounting office for the respective ministries. The AD will perform their role based on three major components: (1) maintain accounting books and records, (2) comply with rules and regulations, and (3) prepare financial reports and statements (Rauf et al., 2009).

Data were collected using a structured questionnaire personally administered to the accounting personnel of the federal government. The main criteria that were taken into consideration in choosing the sample was that the ministries and the accounting personnel were involved in the transition process of accrual accounting adoption. Stratified sampling was used to obtain the sample of 135 accounting personnel in various ministries. A total of 119 public sector accounting personnel participated in the survey comprising three major groups - accountants (W41-above), assistant accountant 1 (W27-W36) and assistant accountant 2 (W17-W26). The list of respondents was suggested by the respective association of the respective group. The time taken to complete the questions in the survey by the respondent was about 20 minutes or less. The 119 completed questionnaires were used in the data analysis, representing a response rate of 88 per cent. The distribution of questionnaires is shown in Table 1 below:

Table 1. Respondents for the questionnaire survey

\begin{tabular}{|l|c|c|}
\hline Job Position & Distributed & Collected \\
\hline Accountant (W41 and above) & 42 & 39 \\
\hline $\begin{array}{l}\text { Assistant Accountant } \\
\text { (W27-W36) }\end{array}$ & 42 & 38 \\
\hline $\begin{array}{l}\text { Assistant Accountant } \\
\text { (W17-W26) }\end{array}$ & 51 & 42 \\
\hline TOTAL & 135 & 119 \\
\hline
\end{tabular}

\section{Data Analysis}

\subsection{Descriptive Statistics}

A total of 119 respondents participated in the survey. Of the total number of respondents in this study, 72 per cent were female and 28 per cent were male. The distribution of respondents' ages were 3 per cent between 18 and 25 years, 60 per cent between 26 and 35 years, 27 per cent between 36 and 45 years and 10 per cent over 46 years old. In terms of respondents' marital status, 76 per cent were married, 23 per cent were single and 1 per cent was other status. Among these respondents, 3 per cent had a professional qualification, 39 per cent had a degree or master's degree or doctorate of philosophy, 50 per cent had a diploma or certificate and 8 per cent had SPM or STPM. Regarding the job position, 33 per cent were accountants, 32 per cent were assistant accountant 1 and 35 per cent were assistant accountant 2. From the total, 15 per cent had less than five years length of service, 54 per cent had served the government between five and ten years, and 31 per cent had more than ten years of service. The profile of the respondents is shown in Table 2: 
Table 2. Demographic profile of respondents

\begin{tabular}{|c|c|c|c|}
\hline Background & Categories & Frequency & $\%$ \\
\hline \multirow[t]{2}{*}{ Gender } & Male & 33 & 28 \\
\hline & Female & 86 & 72 \\
\hline \multirow[t]{4}{*}{ Age } & $18-25$ years & 3 & 3 \\
\hline & $26-35$ years & 71 & 60 \\
\hline & $36-45$ years & 32 & 27 \\
\hline & 46 years and above & 13 & 10 \\
\hline \multirow[t]{3}{*}{ Marital status } & Single & 27 & 23 \\
\hline & Married & 90 & 76 \\
\hline & Others & 2 & 1 \\
\hline \multirow[t]{4}{*}{ Education level } & Professional qualification & 4 & 3 \\
\hline & Degree/Master/PhD & 45 & 39 \\
\hline & Diploma/Certificate & 60 & 50 \\
\hline & SPM/STPM & 10 & 8 \\
\hline \multirow[t]{3}{*}{ Job position } & $\begin{array}{l}\text { Accountant (W41 and } \\
\text { above) }\end{array}$ & 39 & 33 \\
\hline & $\begin{array}{l}\text { Assistant Accountant } 1 \\
\text { (W27-W36) }\end{array}$ & 38 & 32 \\
\hline & $\begin{array}{l}\text { Assistant Accountant } 2 \\
\text { (W17-W26) }\end{array}$ & 42 & 35 \\
\hline \multirow[t]{3}{*}{ Length of service } & Less than 5 years & 18 & 15 \\
\hline & $5-10$ years & 64 & 54 \\
\hline & More than 10 years & 37 & 31 \\
\hline
\end{tabular}

The modified scale of readiness for change in this study was based in part on McNabb \& Sepic (1995), and Shah (2009) including the pre-test and pilot test for this study. This scale consists of twelve attributes to measure individual readiness behaviour rated on a seven-point scale ranging from strongly disagrees to strongly agree. The 12 attributes were from the literature (Hanpachern, Morgan, \& Griego, 1998; Madsen, Miller, \& John, 2005; Shah \& Shah, 2010) and refined in the pre-test and pilot test for this study. The Cronbach's Alpha for the scale was 0.93, indicating good internal consistency as suggested by Nunnally (1967) cited in Lund (2003). Analysis of variance (ANOVA) with Tukey Honestly Significant Differences (HSD) post hoc multiple comparisons was used to test between job position, length of service and readiness for change.

Table 3 summaries the descriptive statistics of the readiness for change attributes. The mean score of the 11 dimensions were relatively high ranging from 6.07 to 5.42, on a scale of 1 to 7 . This indicated that the public sector accounting personnel strongly agreed that they are ready 
to change to the new accounting environment. Among the 11 attributes, learn new things showed the highest (mean $=6.07$ ) while the lowest was improve current tasks (mean= 5.42). This suggested that the respondents are ready to learn new things in order to improve the public sector transparency and accountability. The lowest score for improve current tasks suggested that the respondents believed that they have to improve the accounting records, especially complete records of government assets in order to make the accounting change a success.

However, the respondents slightly disagreed and were not ready to take responsibility if the accounting change failed in their area. This was represented by the mean score of 4.89 . This suggested that they are not ready to be accountable if the implementation was not achieved.

Table 3. Descriptive statistics of readiness for change attributes

\begin{tabular}{|l|c|c|c|c|}
\hline Attributes & Mean & SD & MIN & MAX \\
\hline Learn new things & 6.07 & 0.85 & 4 & 7 \\
\hline Support change & 5.99 & 1.05 & 3 & 7 \\
\hline Accept change & 5.97 & 0.86 & 4 & 7 \\
\hline Work in new environment & 5.95 & 0.86 & 4 & 7 \\
\hline Be part of changes & 5.93 & 0.97 & 4 & 7 \\
\hline $\begin{array}{l}\text { Change the way doing } \\
\text { work }\end{array}$ & 5.93 & 0.82 & 4 & 7 \\
\hline Work harder & 5.83 & 0.87 & 4 & 7 \\
\hline Selling ideas & 5.66 & 0.99 & 3 & 7 \\
\hline Create new ideas & 5.64 & 0.95 & 3 & 7 \\
\hline $\begin{array}{l}\text { Solve accounting problem } \\
\text { in ministries }\end{array}$ & 5.61 & 0.99 & 3 & 7 \\
\hline Improve current tasks & 5.42 & 1.34 & 1 & 7 \\
\hline Take responsibility & 4.89 & 1.40 & 1 & 7 \\
\hline
\end{tabular}

\subsection{ANOVA Results}

The analysis of variance (ANOVA) was conducted to examine the relationship between job position, length of service and readiness for change. The test was employed to compare the mean difference. Post-hoc comparisons using the Tukey HSD test indicated that there was no significant difference between the mean score for accountant (mean=69.67, $\mathrm{SD}=9.348$ ), assistant accountant 1 (mean=69.87, $\mathrm{SD}=7.726$ ) and assistant accountant 2 (mean=67.31, $\mathrm{SD}=10.351$ ).

The mean score for length of service of less than five years (mean=72.22, $\mathrm{SD}=8.135$ ), between five and ten years of service (mean=68.06, $\mathrm{SD}=8.674$ ) and for services more than ten years (mean=68.73, $\mathrm{SD}=10.511)$. Table 4 proves that there are no significant differences at the 0.05 level between job position and readiness for change $(p$-value $=0.385)$ and between 
length of service and readiness for change $(p$-value $=0.241)$. These results indicated that there are no significant mean differences for job position, length of service, and readiness for change between the groups.

Table 4. The table of ANOVA

\begin{tabular}{|c|c|c|c|c|}
\hline & \multicolumn{2}{|c|}{ Job Position } & \multicolumn{2}{|c|}{ Length of service } \\
\hline & F-stat & Sig & F-stat & Sig \\
\hline $\begin{array}{ll}\text { Readiness } & \text { for } \\
\text { change } & \end{array}$ & 0.963 & 0.385 & 1.442 & 0.241 \\
\hline
\end{tabular}

\section{Conclusion}

Based on the results of this study, it can be concluded that employee behaviour influences readiness for change in an organization. This study determines which attributes measure the readiness for change among public sector accounting personnel in Malaysia. The results show that the public sector accounting personnel are ready and have positive behaviour for the 11 attributes that measure the readiness level. Learn new things have the highest mean score. However, they have an adverse behaviour to be accountable if the transformation fails in their area.

The demographic factors of job position and length of services are not related with readiness for change for Malaysian federal government accounting personnel. This result is consistent with the study by Madsen et al. (2005) and Shah \& Shah (2010). The results of this study prove that regardless of their job position and length of service they are ready to change and have positive behaviour towards change. This finding is consistent with the results of Armenakis et al. (1993) and Vakola (2014), which confirms that if an individual employee holds a positive view that the change has positive implications for them and the organization, they will be ready and support the change. In this study, the attribute of learn new things reflects that the federal government accounting personnel are ready to change. The implication to the government is that the transformation to accrual-based accounting will not having much problem due to the positive behaviour among the accounting personnel of Malaysian federal government. This study also suggests that future research should explore the new relationship of the demographic factors due to the lack of consensus in the findings.

\section{References}

Armenakis, A. A., Harris, S. G., \& Mossholder, K. W. (1993). Creating readiness for organizational change. Human Relations, 46(6), 681-703. http://dx.doi.org/10.1177/001872679304600601

Baker, R., \& D.Rennie, M. (2006). Forces leading to the adoption of accrual accounting by the Canadian Federal Government: An Institution Perspective. Canadian Accounting Perspectives, 5(1), 83-112. http://dx.doi.org/10.1506/206K-RV7L-2JMN-W3D3

Barton, A. (2005). Issues in accrual accounting and budgeting by government. Agenda, 12(3), 211-226. 


\section{1l Macrothink}

Journal of Management Research

ISSN 1941-899X

2015, Vol. 7, No. 2

Broadbent, J., \& Guthrie, J. (1992). Changes in the Public Sector: A review of recent "alternative" accounting research. Accounting, Auditing \& Accountability Journal, 5(2), 3-31. http://dx.doi.org/10.1108/09513579210011835

Cunningham, C. E., Woodward, C. A., Shannon, H. S., Maclntosh, J., Lendrum, B., Rosenbloom, D., \& Brown, J. (2002). Readiness for organizational change : A longitudinal study of workplace, psychological and behavioural correlates. Journal of Occupational and Organizational Psychology, 75, 377-392. http://dx.doi.org/10.1348/096317902321119637

Ellwood, S., \& Newberry, S. (2007). Public sector accrual accounting: Institutionalising neo-liberal principles? Accounting, Auditing \& Accountability Journal, 20(4), 549-573. http://dx.doi.org/10.1108/09513570710762584

Guthrie, J., \& Humphrey, C. (1996). Public sector financial management developments in Australia and Britain: Trends and contradictions. Research in Governmental and Nonprofit Accounting, 9, 283-302.

Hanpachern, C., Morgan, G. A., \& Griego, O. V. (1998). An extension of the theory of margin: A framework for assessing readiness for change. Human Resource Development Quartely, 9(4), 339-350. http://dx.doi.org/10.1002/hrdq.3920090405

Hood, C. (1995). The "New Public Management" in 1980s: Variations on a theme. Accounting, Organizations and Society, 20(2/3), 93-109. http://dx.doi.org/10.1016/0361-3682(93)E0001-W

Isa, C. R., Saleh, Z., \& Jusoh, R. (2011). Commitment to Change among Government Accountants in Malaysia. Asian Journal of Business and Accounting, 4(2), 71-92.

Kavaliauskaite, V., \& Jucevicius, R. (2010). Readiness of public institutions for contracting. Economics and Management, 15, 587-596.

Lund, D. B. (2003). Organizational culture and job satisfaction. Journal of Business \& Industrial Marketing, 18(3), 219-236. http://dx.doi.org/10.1108/0885862031047313

Madsen, S. R., Miller, D., \& John, C. R. (2005). Readiness for organizational change: Do organizational commitment and social relationships in the workplace make a difference? Human Resource Development Quartely, 16(2), 213-233. http://dx.doi.org/10.1002/hrdq.1134

McNabb, D. E., \& Sepic, F. T. (1995). Culture, Climate , and Total Quality Management : Measuring Readiness for Change. Public Productivity \& Management Review, 18(4), $369-385$.

Ministry of Finance Malaysia. (2011). Economic Report 2010/2011. Financial Statistics, 584, 99-122. http://dx.doi.org/10.1057/fs.2010.168

Othman, O., Ismail, M. S. H., Ismail, S. S. S., Saidin, S. Z. H., Rahim, M. S. H., Salleh, M. S. M., ... Marlina Mohd Lazim. (2007). Public sector accounting in Malaysia (p. 161). Singapore: Cengage Learning Asia Pte Ltd. 


\section{Macrothink}

Journal of Management Research

ISSN 1941-899X

2015, Vol. 7, No. 2

Pallot, J. (1992). Elements of a Theoretical Framework for Public Sector Accounting. Accounting, Auditing \& Accountability Journal, 5(1). http://dx.doi.org/10.1108/09513579210008244

Peach, M., Jimmieson, N. L., \& White, K. M. (2005). BELIEFS UNDERLYING EMPLOYEE READINESS TO SUPPORT A BUILDING RELOCATION: A Theory of Planned Behavior perspective. Organization Development Journal, 23(3), 9-22.

Rauf, F. A., Yusoff, H., Yatim, N., Poobalan, U. R., Salleh, S. C., \& Othman, R. (2009). Public Sector Accounting: Malaysian Context (Second., p. 271). Petaling Jaya: Pearson Prentice Hall Malaysian Sdn Bhd.

Saleh, Z., Isa, C. R., \& Hasan, H. A. (2012). Accrual accounting: Change and managing change. IPN Journal of Research and Practice in Public Sector Accounting and Management, 2(Special Issue), 41-52.

Saleh, Z., \& Pendlebury, M. W. (2006). Accruals Accounting in Government - Developments in Malaysia. Asia Pacific Business Review, 12(4), 421-435. http://dx.doi.org/10.1080/13602380600574595

Shah, N. (2009). Determinants of Employee Readiness for Organisational Change. Brunel University.

Shah, N., \& Shah, S. G. S. (2010). Relationships between employee readiness for organisational change, supervisor and peer relations and demography. Journal of Enterprise Information Management, 23(5), 640-652. http://dx.doi.org/10.1108/17410391011083074

Siddiquee, N. A. (2006). Public management reform in Malaysia: Recent initiatives and experiences. International Journal of Public Sector Management, 19(4), 339-358. http://dx.doi.org/10.1108/09513550610669185

Vakola, M. (2014). What'd is there for me? Individual readiness for change and the perceived impact of organizational change. Leadership \& Organization Development Journal, 35(3), 195-209. http://dx.doi.org/10.1108/LODJ-05-2012-0064

Weber, P. S., \& Weber, J. E. (2001). Changes in employee perceptions during organizational change. Leadership \& Organization Development Journal, 22(6), 291-300. http://dx.doi.org/10.1108/01437730110403222

Wynne, A. (2004). Is the move to accrual based accounting a real priority for public sector accounting? (pp. 1-30). ACCA. Retrieved from www.accaglobal.com

\section{Copyright Disclaimer}

Copyright for this article is retained by the author(s), with first publication rights granted to the journal.

This is an open-access article distributed under the terms and conditions of the Creative Commons Attribution license (http://creativecommons.org/licenses/by/3.0/). 